\title{
Synthesis of MK-7655
}

Synthesis of Natural<smiles>O=C(NC1CCN(C(=O)OCc2ccccc2)CC1)C1CCC(=O)N1C(=O)OCc1ccccc1</smiles>

$t$-BuOK (1.5 equiv) $\left[\mathrm{Me}_{3} \mathrm{~S}=\mathrm{O}^{+I^{-}}(1.7\right.$ equiv)

DMSO, r.t., $1 \mathrm{~h}$ $71 \%(167 \mathrm{mmol} \mathrm{scale})$

A

mp not reported<smiles>O=C(NC1CCN(C(=O)OCc2ccccc2)CC1)[C@@H]1CC[C@@](O)(CCBr)CN1[18OH]</smiles>
mp not reported<smiles>O=C(NC1CCN(C(=O)OCc2ccccc2)CC1)[C@@H]1CCC(NOCc2ccccc2)CN1</smiles>

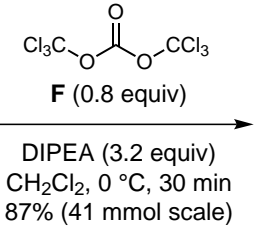
$\mathrm{CH}_{2} \mathrm{Cl}_{2}, 0^{\circ} \mathrm{C}, 30 \mathrm{~min}$
$87 \%(41 \mathrm{mmol}$ scale $)$ mp not reported<smiles>O=C(NC1CC[NH2+]CC1)[C@@H]1CCC2CN1C(=O)N2OS(=O)(=O)[O-]</smiles>

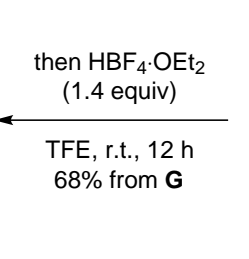
mp not reported<smiles>CC(C)(C)OC(=O)NC1CCN(C(=O)OC(C)(C)C)CC1</smiles>

[ $\left[\right.$ r (cod) $\mathrm{Cl}_{2}$ ( 0.01 equiv) $\mathrm{PhMe}, 80^{\circ} \mathrm{C}, 10 \mathrm{~h}$ $112 \mathrm{mmol}$ scale<smiles>CC(=O)N1CCC(NC(=O)C2CCC(=O)CC2)CC1</smiles>

Significance: MK-7655 is a potent $\beta$-lactamase inhibitor. It is in clinical trials for the treatment of bacterial infections in conjunction with $\beta$-lactam antibiotics. The bicyclic urea is highly reactive and a major challenge was to find conditions for its formation and preservation during the construction of the aminoxy sulfate. This work features the first practical application of the $\mathrm{N}-\mathrm{H}$ insertion of a sulfoxonium ylide $(\mathbf{D} \rightarrow \mathbf{E})$ in a complex synthesis.

SYNFActs Contributors: Philip Kocienski

Synfacts 2012, 8(1), $0001 \quad$ Published online: 19.12.2011 Dol: 10.1055/s-0031-1289917; Reg-No.: K07011SF
Comment: The synthesis depicted delivered multikilogram quantities of API in twelve steps and $10 \%$ overall yield. MK-7655 is only stable in the $\mathrm{pH}$ range of 4-8; therefore, removal of the Boc group in the final step cannot be achieved under the usual acidic conditions. After extensive experiments, 1.4 equivalents of $\mathrm{HBF}_{4} \cdot \mathrm{OEt}_{2}$ in trifluoroethanol successfully removed the Boc group. 